\title{
健診で認知症をどのように評価し見いだすか： 脆弱化との関連を中心にして
}

\author{
一般財団法人ライフプランニングセンター1）日本大学医学部総合健診センター2) \\ 道場 信孝 ${ }^{1 ）}$ 久代 登志男 ${ }^{2)}$ 日野原 重明 ${ }^{1)}$
}

20世紀から今日に至る公衆衛生学上の大きな功績の一つは平均余命の倍増であるが、それによって 生じている老年症候群（Geriatric Syndrome: GS）の増加が未知で新たな脆弱化や認知症といった健 康問題をもたらしている。これらはいずれも身体的、そして心理・精神的に依存の状態であり、経済 的にも医療の面でも大きな負担となっている。脆弱化は自立能の維持との関わりが深く、受診、入院、 死のリスクを高めるが、その定義、診断、臨床における対応について明確なコンセンサスはない。他方、 認知機能の退行は高齢者に多いが、その現れ方は軽症から重症に至る幅広い実在であり、その初期診 断には多くの問題がある。しかし、脆弱化と認知症との関連を理解することには以下のような二つの 利点がある：(1) 脆弱化と認知機能障害は相互に危険因子となり得る、(2) 相互の関わりを理解すること によって両者の予防やケアに新たな手だてが期待できる。近年、GS では栄養、動作、身体活動、筋力、 持久力、バランス、認知機能、感覚、ムード、対応、社会的関わり、社会的支援など多くの指標を評 価の対象としているが、脆弱化を特徴づける有意な徵候としては身体機能、歩行速度、認知機能を挙 げる報告が多い。また、脆弱化と認知症には関連性はあるが、明らかに異なった実在であるとするの がコンセンサスである。Robertson ら（2013）は frailty, cognition, Alzheimer disease key word と してPub Med で検索した結果を1,314の研究報告をもとにして両者の関連について review しているが、 それによれば、両者を関連づけるエビデンスとして七つの横断研究と、三つの縦断研究が挙げられてい る。脆弱化の基準としては Fried らの基準、Rockwood らの基準、SOF、Z-score などが用いられ、ま た、認知機能の評価にはMMSE をはじめとする多くの評価法が用いられている。これらを総合すると 脆弱化は認知機能低下の予測因子であり、同時に認知機能の低下は脆弱化の予測因子であることが強 く示唆され、脳の神経病理、ホルモン機能の異常から生じる心臓血管リスク、心理・精神的要因など に多岐にわたる種々のメカニズムが想定されている。われわれは2002年より407例（平均年齢78 44 歳、 女性55\%）の地域在住の高齢者について 5 年間の前向きコホート研究を行い、脆弱化の予測因子を求め た。認知機能にはMDS の cognitive performance scale と self-reported cognitive change、frailty の評 価には CSHA-CFS を用いた。脆弱化に関する単変量解析では18項目について有意差を認め、これらに 関する多変量解析から以下の 4 指標が予測因子として抽出された。: 1) 歩行速度 (cut-off 值: $3 \mathrm{sec} / 5 \mathrm{~m}$ )、 (2) 脈圧 (cut-off 值 : 60mmHg)、(3) 記憶力の減退、(4) 聴機能低下。これらをもとにして脆弱化の予測式 から得られた感度（4 項目全てを有する）と特異度（4 項目全てなし）はそれぞれ $70 \%$ と $93 \%$ であった。 これらの 4 因子はいずれも認知症との関わりがあり、また、この結果は脆弱化の予測の可能性を示唆 するものであった。これらの予測因子の中でも聴機能の低下は通常の純音による機能評価では診断で きない中枢性の聴覚処理機能障害（auditory processing disorder: APD）であり、今後、総合健診の中 でも簡易で正確に施行し得る機能評価法の開発が望まれる。 


\section{【略歴】}

1960年 千葉大学医学部卒業

1972年 コーネル大学医学部神経内科助教授

1973年 千葉大学医学部第 1 生理学教室助教授

1986年 帝京大学医学部第 3 内科学教室教授

2001年 帝京平成大学健康メディカル学部栄養学科教授

2001年 一般財団法人ライフプランニングセンター最高顧問

現在に至る

\section{【主な所属学会】}

日本内科学会功労会員

日本循環病学会功労会員

日本高血圧学会功労会員

日本心臟病学会功労会員

日本心臟リハビリテーション学会名誉会員 